\title{
Organisation and Reforms of the Electricity Sector in Slovenia
}

\author{
by
}

Nevenka Hrovatin

\author{
Faculty of Economics, University of Ljubljana \\ $\&$ \\ Jelena Zoric
}

Faculty of Economics, University of Ljubljana

$\&$

Russell Pittman

U.S. Department of Justice

\section{CCP Working Paper 08-13}

\begin{abstract}
After the disintegration of Yugoslavia in 1991, Slovenia became an independent state and entered into the transition period from a planned to a market economy. Slovenia's relative prosperity has been a key factor in the country's approach to reform, which has differed substantially from other Central and Eastern European countries. It has followed a gradualist approach to change, frequently postponing many key structural reforms (World Bank, 2006). After it had successfully completed the transition process, Slovenia became a new EU member state on 1 May 2004. Its political and economic system, legislation and institutional setting fully correspond to those in the EU. Today Slovenia is considered to be one of the most successful (ex-) transition countries from Central East and South East Europe. On 1 January 2007 Slovenia was the first among the new EU member states to join the EMU and introduce the euro as its official currency.

The process of liberalisation of the Slovenian electricity market to a large extent resembles what other EU countries were witnessing. To comply with the EU legislation, namely the Electricity Directives (96/92/EC) and (2003/54/EC), Slovenia had to adopt the Energy Act (1999) and the amended Energy Act (2004). The Slovenian electricity market has been partially opened since 2001. From 1 July 2007, when households became eligible customers, the electricity market has fully opened.
\end{abstract}

\section{October 2007}

JEL Classification Codes: L94, Q40, Q48

Keywords: electricity reform, restructuring, competition, South East Europe, liberalisation 


\section{Acknowledgements:}

The views expressed are not those of the U.S. Department of Justice. The support of the Economic and Social Research Council is also gratefully acknowledged.

\section{Contact details:}

Nevenka Hrovatin, Faculty of Economics, University of Ljubljana, Kardeljeva pl. 17, 1000 Ljubljana, SLOVENIA

Nevenka.hrovatin@ef.uni-li.si

Jelena Zoric, Faculty of Economics, University of Ljubljana, Kardeljeva pl. 17, 1000 Ljubljana, SLOVENIA

Jelena.zoric@ef.uni-li.si

Russell Pittman, U.S. Department of Justice, Economic Analysis Group Antitrust Division, USA

Russell.Pittman@usdoj.gov 


\section{Background on Electricity Sector}

In 1991 the vertically integrated electricity system in Slovenia was split into independent companies in generation, transmission and distribution. Power plants were utilised on an integrated basis in accordance with a daily dispatch plan prepared by the transmission company ELES. ${ }^{1}$ Electricity was sold on the basis of short-term agreements between generators, the transmission company and distribution companies. Distribution companies operated as regional monopolies with exclusive rights to supply electricity to households and industrial customers within their service area. Sales revenues were distributed on the basis of administratively determined costs of each company. In the case of generation units, this resulted in considerable crosssubsidisation. The inexpensive hydropower plants subsidised the expensive thermal power plants, which in turn contributed to maintaining lower electricity prices for end-users.

The Government controlled prices for end-users. They were uniform for each customer group throughout the country. Electricity was perceived as a "social good" which should be available to everyone at affordable prices. As a result, electricity prices did not cover costs, nor did they take into account a fair return on investments. Since the independence of Slovenia, electricity prices have also been one of the tools to tackle high inflation (Hrovatin, 1999).

In 1996 Slovenia signed an accession agreement with the EU, which came into force in 1999. This was an important 'push' factor for introducing the electricity reforms as Slovenia had to harmonise its legislation with the acquis communautaire. As a result the new Energy Act was passed in 1999, which dictated changes in the directions of liberalisation and increased efficiency of the electricity sector according to the EU rules. It has significantly transformed the institutional framework, organisation and operating environment of the electricity companies.

The state continues to play a major role in the Slovenian electricity sector. It is still a majority owner of electricity companies, the only exception being a nuclear power plant which is jointly owned with Croatia. The Government also appoints managers of the electricity companies. Privatisation is anticipated in the near future. Unlike other transition countries that decided to sell their electricity companies mostly to foreigners in order to tackle severe macroeconomic imbalances and to finance modernisation of the system, Slovenia did not face such troubles. Therefore, it was able to postpone the privatisation process.

\section{Electricity Reform Programme}

In 1999 Slovenia adopted the new Energy Act which followed the Electricity Directive (96/92/EC). The Energy Act envisaged the gradual and progressive

\footnotetext{
${ }^{1}$ In addition, ELES carried out short-term technical and economic planning, system optimisation, technical relations with UCPTE and electricity trade.
} 
opening up of the market which should lead to an increase in economic efficiency and increased competitiveness in the electricity sector.

Like elsewhere in the EU, electricity market reforms involved the introduction of competition into electricity generation and supply activities and the design of an organised power market to facilitate electricity trading. On the other hand, transmission and distribution activities, due to their natural monopoly character, remain regulated. Regulated Third Party Access (TPA) was chosen for the access to the grids. The independent regulator Energy Agency (EA), founded in 2001, became responsible for regulating network charges.

In the first stage, running from 15 April 2001 until 2003, the electricity market was opened to domestic purchases. In the second stage, starting at the beginning of 2003, foreign companies were allowed to participate in the market while eligible customers were entitled to import electricity under commercial agreements. The threshold for defining eligible customers has been set relatively low. All customers with a connected capacity of more than $41 \mathrm{~kW}$ at one location obtained the right to buy electricity freely. This amounted to around $64 \%$ of final consumption. Most companies in the manufacturing sector and services became eligible customers. Mainly households and some lowvoltage customers had to purchase electricity directly from distribution companies.

In order to comply with the new Electricity Directive (2003/54/EC), Slovenia adopted the amended Energy Act in 2004. On 1 July 2004 all customers, except households, became eligible customers. This resulted in $75 \%$ opening of the electricity market. Finally, the Slovenian electricity market was fully opened on 1 July 2007, as were other markets in the EU.

Although the electricity market has been fully liberalised, objectives of the reforms have not been fully achieved. Concentration in the generation and retail markets remains relatively high. To some extent this is the result of the small size of the electricity market in Slovenia, the lack of generation and interconnection capacities with neighbouring countries and the ownership structure of electricity companies. In addition it seems that it has been more important to the Government to protect domestic generators than to enhance competition in the power market. This may explain why the majority of the state owned power plants merged into the holding of electricity companies (HSE) in 2001. Furthermore, reorganisation of the electricity sector in 2006 that resulted in the creation of two pillars in electricity generation can also be seen as creating national champions rather than enhancing competition.

\subsection{Regulation of the Use of Network Charges}

\subsubsection{Incentive-Based Price Cap Regulation}

The Agency is responsible for regulation of charges for the use of electricity distribution and transmission networks and since 2006 also for the use of gas transportation and distribution networks. With the help of foreign consultants sponsored by EU funds Slovenia launched an incentive-based price cap (CPI$X)$ regulation mechanism. Unlike the UK, Slovenia opted for a three-year 
regulatory period. This allowed for quick corrections in the regulatory system if the first regulatory period (2003-2005) had shown severe drawbacks. In the new regulatory period (2006-2008) the EA also started to regulate the quality of service.

The price cap mechanism has significantly changed the past practice of price determination where electricity prices for all consumer groups were controlled by the Government. Since the electricity prices (including the use of network charges) were set below the full cost level, it is not surprising that the electricity prices had to be increased. Unlike in the UK, where X-factors for electricity utilities were always positive, implying reductions in prices, in Slovenia initial Xfactors were negative. However, the required increases in prices could not have been carried out at once. A gradual approach was needed to prevent inflationary pressures and social tensions.

For gradual elimination of efficiency discrepancies between Slovenian distribution companies and foreign companies operating close to the efficient frontier, the EA decided to exhaust on average $80 \%$ of the efficiency improvement potentials during the first regulatory period. According to these calculations the regulated utilities in Slovenia were required to decrease their annual costs from $4 \%$ to $9 \%$ (EA, 2004b). Similar findings for the necessary efficiency improvements were found by Fillipini et al. (2004) and Hrovatin et al. (2005). In the new regulatory period the expected increase in productivity is $3 \%-5 \%$ (EA, 2005). This should suffice to reach on average an expected $85 \%$ efficiency of foreign counterparts.

\subsubsection{Required Increases of the Network Charges}

The price cap model resulted in the need to increase the distribution network charge by $15.56 \%$ annually, and the transmission network charge by $13.19 \%$ annually, for the period 2003-2005 (EA, Annual Report 2003, p.18).

Although the EA should act independently, the Government soon started to intervene in the setting of network charges to prevent envisaged increases. At the end of the first year of the regulatory period, in December 2003, the Government set a fixed network charge for the following six-month period by ordinance and required the EA to abandon the anticipated increase in network charges according to the price cap formula. As a result, in July 2004, the EA modified the calculation of required revenues from the network charge for 2004 and 2005 (EA, 2004a) so that planned increases in network charges did not materialise. The driving force for the governmental intervention was the inflationary anchor - the attempt to bring inflation down to the Maastricht level which would qualify Slovenia to join the EMU. The fulfilment of this macroeconomic goal was in direct conflict with the professional mission of the Agency to do its job in tariff rebalancing. Discretionary power of the Agency was in this way jeopardised and would hopefully be seen as a one-off event. Independence of the regulators is one of the key priorities of the EU which has been questioned in Slovenia.

Changes in the regulatory framework for the new regulatory period 2006-2008 were discussed in a consultation paper and were finally incorporated into the 
amended acts of the Agency. Charges for the transmission network will not change in the whole period. In 2006 charges for distribution networks also remained the same, to be followed by an increase of $3.5 \%$ in 2007 and by $3.2 \%$ in 2008 (EA, 2006). These low anticipated increases in tariffs also cast some doubt on whether the network charges were set solely on professional grounds without any political interventions aiming at preventing inflationary pressures in the future. In fact the Agency itself implicitly recognised this by setting a requirement that distribution utilities increase efficiency more than calculated by the model. ${ }^{2}$ It seems that this should offset the necessary increases in tariffs.

\subsubsection{Network Charges, End-user Prices and Consumer Issues}

Network charges in Slovenia are based on the postage-stamp principle for each customer group. Distribution utilities have quite different average costs that reflect differences in the amount of electricity distributed, load factor, population density and geographical varieties of different regions. Consequently, there is a transfer mechanism in place to offset the regional cost differences by redistributing revenues among the five distribution utilities.

The use of a network charge is a broader category than the network charge itself. In addition to transmission and distribution charges it consists of ancillary services, preferential dispatch and a contribution for the work of the EA and the power exchange Borzen. Ancillary services are provided mainly by domestic electricity generating companies.

To support the production of electricity that would not be competitive in the open market (i.e. generators using renewable energy sources and waste products and generators with stranded costs) a system of preferential dispatch is applied in Slovenia. The system of preferential dispatch allows qualified producers to sell their electricity at guaranteed prices, which exceed prices in the liberalised electricity market. All producers using renewable resources are entitled to such support. TSO ELES has to purchase all electricity produced in the subsidised utility through the system of preferential dispatch. The difference between the guaranteed and the market-based prices is covered by a fraction of the use-of-network charge. The generation company entitled to a preferential dispatch could also sell electricity in the power exchange Borzen at market-based prices. In this case it is compensated with a difference between the lower market-based price and higher subsidised price. For the coverage of stranded investments, the EU provisions which allow for preferential utilisation of the electricity generated from domestic primary sources (accounting for up to $15 \%$ of consumption) are used. The TPP Trbovlje loss from the electricity revenues earned in the market is covered under this arrangement. CHP TETOL lost the status of a qualified producer, since it has been found that it was not above-average efficient.

\footnotetext{
2 The EA introduced additional increases in efficiency: "Because of the governmental orientation in December 2005 to introduce the euro and to lower inflation it is required that the system operators additionally raise efficiency, on average in 2006 for $2.8 \%$, in 2007 for $2.6 \%$ and in 2008 for $2.7 \%$ " (EA, 2005).

${ }^{3}$ For example, in Filippini et al. (2004) it has been found that average costs of Slovenian electricity distribution utilities in 2000 varied from $€ 24.7$ to $€ 32.2$ per MWh of electricity distributed.
} 
The structure of the use of network charge and the end-user price of electricity in 2005 is shown in Table 1 for three customer groups (large industrial customers, small industrial customers and households). In 2005 the average price for the use of networks in Slovenia for all customer groups was $2.2 \mathrm{c} €$ per kWh. Customers connected to the high voltage network were paying 0.49 $\mathrm{c} €$ per $\mathrm{kWh}$, industrial customers connected to the medium voltage $1.41 \mathrm{c} €$ per $\mathrm{kWh}$, and customers connected to the low voltage network 4.41c€ per kWh (due to the higher charge related to the use of the distribution network) (EA, 2006).

The end-user price of electricity consists of the use of the network charge and the electricity price. In 2005 end-user prices were below the EU-25 average for all three customer groups. The electricity price for eligible customers depends on the amount of consumed electricity and the profile of consumption. For example, lower consumption and a volatile daily or monthly consumption (as measured by the load factor) is typically associated with the higher price of electricity. It can be noticed that for large industrial customers the share of electricity consumed in the final electricity price is relatively high, almost $80 \%$. For small industrial customers and households it is considerably lower, while the share of the fixed part of the price (i.e., components of the use-of-network charge) is higher than for the large industrial customers. The use-of-network charge has a fixed and a variable element, while all other elements of the final electricity price (electricity supplied, supply costs and excise) depend only on the amount of electricity consumed.

In 2004 consumption expenditure of households for energy amounted to $6.3 \%$ of total expenditure, while electricity expenditures alone amounted to $2.6 \%$ (Statistical Yearbook 2006). Since electricity is perceived as a social good, the distribution system operator is not allowed to stop the supply of electricity below the existentially needed consumption. In this way the most vulnerable customers are protected. At some point after 1 July 2007 the poorest households could be exempt from paying for electricity, if they provide required evidence on their status to the distribution system operator. The mechanism has not been implemented in practice yet.

Before full market opening, the use-of-network charge was regulated by the EA, while other elements of the final electricity price for households were controlled by the Government. As meeting the Maastricht criteria for joining the EMU was one of the principal objectives of macroeconomic policy, electricity prices for households were typically allowed to increase by less than the official inflation rate. Currently, the household electricity prices are about 20\% lower than the market prices (i.e. prices at which distribution companies buy electricity). Therefore, after 1 July 2007, increases in electricity prices for households were expected to reach the level of market-based prices. Nevertheless, to avoid opposition from the public this should happen gradually.

\subsection{Corporatisation and Privatisation of State Owned Utilities}

The current Slovenian electricity industry ownership structure results from the ownership transformation process of public utilities (Hrovatin, 1999). Unlike general Slovenian companies, whose ownership transformation was laid down 
by the Law on Ownership Transformation of Business Enterprises (1993), the ownership transformation of public utilities was subject to the Public Utilities Act (1993).

According to this Act, each utility was reorganised into a shareholding company. Then the infrastructure of each utility was nationalised. The remaining 'social capital' 4 was transformed according to the financial participation of the state or/and local communities in company operations (current operation and investments) over previous years. A utility became a public enterprise if the socially accumulated financial sources exceeded $51 \%$. Otherwise, it was transformed into a private enterprise. For the remaining social capital of both public and private utilities, the privatisation methods envisaged by the Law on Ownership Transformation of Business Enterprises (1993) applied.

As a result of the nationalisation of infrastructure, electricity companies would have ended up with almost negligible social capital to which general privatisation methods could be applied. To avoid transaction costs of the ownership transformation procedure, the Government passed laws declaring the $100 \%$ state ownership of generation companies and the transmission company ELES. However, in spite of the relatively small proportion of social capital which could have been freely privatised in line with the company's visions, distribution companies implemented their ownership transformation plans according to the Public Utilities Act (1993).

A significant problem for the state appeared in the mass ownership privatisation process known as the "privatisation gap". In brief this means that around $50 \%$ of vouchers that privatisation funds collected from Slovenian citizens could not have been exchanged for shares. ${ }^{5}$ The Government finally decided to fill in this gap by giving a part of its property (shares) in various companies to the privatisation funds. $20 \%$ of shares of electricity generation and distribution utilities were given to investment funds. As a result, government ownership in generation companies decreased from $100 \%$ to around $80 \%{ }^{6}$ and in distribution companies to $79.5 \%$. This explains why privatisation funds are the second biggest owners (as a group) of Slovenian electricity companies. The transmission company ELES remained $100 \%$ in public hands. In NPP Krško the state holds (through its subsidiary ELES GEN) a $50 \%$ share, as it was built in 1978 as a joint venture with neighbouring Croatia.

\footnotetext{
${ }^{4}$ Before 1991, one of the peculiarities of a market-planned economy in Slovenia (or more broadly, Yugoslavia) was so-called social capital, meaning that enterprises were owned neither by the state nor by individuals but by society as a whole. It was often said that enterprises were owned by everybody in general and nobody in particular. Thus, the enterprises did not have proper owners. The transition process in Slovenia was among others followed by the transformation of ownership, i.e. by nationalisation or privatisation of previously socially-owned public enterprises. Social capital was defined as total value of assets of a firm that should be given to a new owner/owners in the process of ownership transformation. This was first equal to the book value of a firm's equity (i.e. total liabilities less credits). After legislative changes it was also possible to use a dynamic valuation method to establish the value of a firm (based on the discounted future flows).

${ }^{5}$ The reasons for the lack of social capital (i.e. shares) are, for example, provided in Simoneti et al. (2004).

${ }^{6}$ The only exception is Drava RC, where in 2003 the HSE bought a $20.5 \%$ share from the minority shareholders (i.e. mostly investment funds) (EA, 2004).
} 
Generation companies operated as independent companies until July 2001, when the Slovenian Government merged all three hydropower companies, TPP Šoštanj, TPP Brestanica, and the coalmine Velenje (as a sole supplier of coal to the TPP Šoštanj) into the holding company Slovenske Elektrarne (HSE). This was the result of the Government's anticipation that liberalisation of the market would bring generation companies into unequal positions; some of them would be faced with high stranded costs (e.g. TPP Trbovlje) while others would enormously benefit from the market opening (e.g. Drava RC with the lowest average costs). ${ }^{7}$

In 2006 the Government decided to reorganise the generation companies again to bring more competition into the electricity market. To counterbalance the power of the HSE the Government decided to create a second pillar in electricity generation, i.e. the company GEN Energija. It consists of NPP Krško, TPP Brestanica and the Sava RC, which were withdrawn from HSE. Whether the two pillars will in fact enhance competition in the market remains to be seen. The opponents of the latest reorganisation claim that this was done more for political reasons than economic since the two companies (pillars), with quite different cost structures driven by different technologies of power plants, could not really compete in the market. The real competition could stem from the competition from imports which has already been allowed with the liberalisation of the electricity trade. Another driving force for the creation of the second pillar is privatisation which will be explained below.

Another open issue was how to reorganise distribution utilities. The empirical findings have shown (Filippini et al., 2004) that they are too small to exploit economies of scale. Therefore, mergers have been recommended. Tajnikar et al. (2002) for example suggest merging existing distribution utilities into three companies. The Government has been considering the merger of all distribution utilities into a distribution holding. Yet another option would be to merge three distribution utilities (Elektro Gorenjska, Elektro Primorska and Elektro Ljubljana) with the first pillar and the remaining two (Elektro Maribor and Elektro Celje) with the second pillar. With this, two strong vertically integrated suppliers of electricity would be founded that could compete in the domestic market. This structure would, in the Government's view, resemble some strong vertically integrated utilities in neighbouring countries. Finally it was decided to keep them legally independent, but to merge the distribution system operators into a new company SODO (Distribution System Operator) (Košir, 2007).

As Slovenia has been criticised by the EU as being one of the member states with the largest state ownership in utilities, the new Government, elected in November 2004, has been seriously considering privatisation of electricity companies. In summer 2006 it revealed its intentions, which should be finally confirmed and elaborated by a privatisation commission in the privatisation

\footnotetext{
${ }^{7}$ The government stated three reasons for the foundation of the HSE: first, to enable joint action of the majority of electricity generating companies in the liberalised market; second, to accomplish the construction of seven new hydropower plants on the river Sava; and third, to increase the competitiveness of the generating companies that merged into the HSE.
} 
programme, which was expected by summer 2007. Distribution utilities are currently not envisaged for privatisation. Privatisation of electricity distribution utilities is constrained by the Energy Act (2004), which allows privatisation of a maximum of $25 \%$ of the state share. The transmission company ELES and the NPP Krško, according to the Energy Act, could not be privatised. This in fact forbids privatisation of the second pillar in electricity generation which shall remain entirely state owned. Privatisation of the second pillar would in fact be quite a complicated process due to the mutual ownership of the NPP Krško with Croatia. On the other hand the first pillar is scheduled for privatisation in two stages. In the first stage the Government would sell $26 \%$ of shares to the strategic investor. In the middle of 2007 the HSE was supposed to be listed in the stock exchange where $23 \%$ of shares would be sold to citizens (5-10\%) and institutional investors (13-18\%). The rest (51\%) will remain in public hands. This will comply with the Energy Act's provision that the Government's share in the generation utilities with more than $75 \%$ of the state ownership should not drop below $51 \%$.

The strategic investor should fulfil certain requirements. It must be an energy company, dealing with various energy activities and should operate in the European market. In addition it must be a financially strong and viable company and must have experiences with similar strategic purchases with a similar aim. It must invest in the HSE (or through the HSE abroad, in particular in South East European countries and CEE region). The HSE must continue to exist as a legal entity with its headquarters in Slovenia. The expectations are that the strategic investor should bring know-how, new technology and experiences into the HSE which will consequently allow the HSE to penetrate into the foreign markets as an investor and supplier. It should also provide financial resources for investment into the generation capacities in Slovenia. Many foreign companies, in fact most of the large European energy companies (EON, RWE, Endesa, CEZ) have already expressed their interest in the purchase. There are also some domestic potential buyers, Petrol (the largest supplier of petrol in Slovenia) and Istrabenz (a private company recently diversifying its business into the energy sector), ${ }^{8}$ although the minister of economic affairs opposes these interests. In his view the first pillar should be sold to a related energy business rather than to the petroleum companies.

The second stage of privatisation of the first pillar (the HSE) is envisaged in three to five years after the completion of the first stage, providing that the first stage has been successfully implemented in terms of the performance of the HSE. The Government will eventually keep $26 \%$ of the shares. In the second stage the shares will be sold to the strategic investor up to $49 \%$ and to private and institutional investors in the stock market.

\footnotetext{
${ }^{8}$ The subsidiary of Istrabenz and Gorenje (a producer of electric appliances) I-G trade (I-G prodaja) has created an alliance with GEN Energija in order to run the supply business of GEN Energija. In 2007 it will be selling $30 \%$ of the electricity of GEN Energija, in $200850 \%$ and in subsequent years $60 \%$. The government has engaged I-G trade as the new pillar GEN Energija has no experience nor experts in the supply business. In fact, the electricity from NPP Krško was traded by ELES GEN, a subsidiary of the transmission company ELES.
} 
Privatisation of the Slovenian electricity industry is quite a contentious issue. Tomšič, the head of the Government group that was preparing the strategic guidelines for privatisation, considers governmental plans on one hand too modest and on the other hand too comprehensive. In his view the NPP Krško could also be sold since many nuclear power plants have been in private hands, while Drava RC, the electricity generator with the lowest costs, should be seen as 'family silver' and hence not scheduled for privatisation. In this case the HSE would lose much of its attractiveness for potential buyers. In addition, according to the minister of economic affairs, Drava RC could not compete in the market alone due to its hydrological conditions and therefore a lack of stable supply of electricity in dry periods. Opposition to the governmental plans also comes from the CEO of the HSE. He claims that the arguments for the sale to the strategic partner do not exist in the HSE's case. The first pillar has, according to the CEO, know-how, technology, expertise and access to financial resources to fulfil its strategic plans without a strategic partner. The Government should in his view keep $51 \%$ of shares and sell the rest to domestic institutional investors and the general public.

According to the latest news from the Ministry of Economy, privatisation of the HSE has been delayed until the reorganisation of the electricity sector is fully completed. Hesitations about privatisation could be understood given theoretical and empirical findings. In general it seems that competition is more important than ownership. Newbery (2001, pp. 177) claims that competition in electricity is essential for the performance of companies no matter whether the company is in public or in private hands. An example is Nuclear Electrics, the publicly owned UK electricity producer which successfully reduced its costs and increased productivity after privatisation of National Power and Powergen. Hall (1998, pp. 32) also argues that there is no evidence proving that the productivity of private producers in electricity is greater than that of public ones. Similar findings in the review of empirical studies could be found in Kwong-leung (1997).

\section{Recent Performance of the Electricity Sector}

The current structure of the Slovenian electricity industry can be considered as a horizontally and vertically disintegrated one (see Figure 1). Electricity is generated in eight large power plants that produce a balanced mix of hydro, thermo and nuclear power. With annual electricity generation of $13,667 \mathrm{GWh}$ in 2005, the Slovenian electricity system is one of the smallest in Europe. Historically, the system was developed as a part of the much larger Yugoslav system. Transport of electricity over the electricity network is carried out by one transmission company and five regional distribution companies. Import and export of electricity in 2005 amounted to 9,326GWh and 9,548GWh, respectively, which was considerably higher than in the year 2004. Import of electricity increased by $91 \%$, while export increased by $86 \%$. If we take only half of the electricity produced by the NPP Krško, the total exports from Slovenia amounted to $6,741 \mathrm{GWh}$ of electricity. The difference between the imported and exported electricity is the amount that Slovenian suppliers had to import to cover Slovenian demand, which was roughly equal to $18 \%$ of 
Slovenia's consumption of electricity. The amount of electricity imported and exported through the Slovenian transmission network in 2005 amounted to $75 \%$ of the annual consumption of Slovenian customers. In the wholesale market, electricity is predominantly sold through contracts, while there is very little electricity trading in the power exchange. In 2005 the end customers, consisting of eligible and tariff customers, consumed 12,389GWh of electricity (EA, 2006).

The Slovenian electricity market is situated between three very different regional markets with very different energy prices. These are the market of Central East Europe, the Italian market, and the market of South East Europe. In 2005 the market of South East Europe had surpluses of production capacities and for this reason its electricity prices were relatively low. ${ }^{9}$ The conditions in the Italian market were completely different, as this market considerably lacks production capacities. The market of Central East Europe has certain surpluses of production capacities (Poland and Czech Republic). Its electricity is cheaper than in Italy and more expensive than in the markets of South East Europe. The positioning of the Slovenian transmission network between the neighbouring networks of Austria, Croatia and Italy represents a substantial challenge for electricity trading. Physical flows of electricity towards Italy increased significantly after some Balkan countries again synchronised their operations with the European energy network (EA, 2006).

\subsection{Generation}

Eight companies are involved in electricity generation in large facilities with more than $10 \mathrm{MW}$ of installed capacity (Table 2). Peak capacity in 2005 amounted to $2,797 \mathrm{MW}$. In addition to the large power plants that are directly connected to the transmission network, the electricity is also generated in small power plants (i.e. mainly small hydroelectric power plants and cogeneration in industrial facilities) that are directly connected to the distribution network. In 2005 Slovenian power plants generated 13,667GWh of electricity. The majority was generated in the nuclear power plant $(41.1 \%)$, followed by thermal (33.6\%) and hydro power plants (22.2\%). Small power plants connected to the transmission and distribution network generated $0.3 \%$ and $2.8 \%$ of electricity, respectively. The shares have been calculated by taking into account the total production of the NPP Krško. However, in line with the bilateral agreement between Slovenia and Croatia, half of the production from the NPP Krško belongs to Croatia. Therefore, the actual production of electricity that belongs to Slovenia was only $10,861 \mathrm{GWh}$.

In 2005 HSE generated $6,642 \mathrm{GWh}$ of electricity, which was $63.6 \%$ of the total production, making the HSE a dominant company. The share of the three largest producers was $96.1 \%$, which indicates a very high concentration in power generation. Creating generation competition does not seem to be one of the government priorities. One reason can be found in very high cost differentials between generating companies which do not facilitate competition. Furthermore, due to the limited cross-border capacities, international flows cannot seriously contribute to increased competition in the Slovenian power

\footnotetext{
${ }^{9}$ These surpluses vanished in the second half of the year 2006 due to a very dry autumn and increased demand for electricity within the region.
} 
market. Most of the imported electricity is exported to Italy, where the electricity prices are considerably higher than in Slovenia. Striving for self-sufficiency in power generation is another concern of politicians. As mentioned in section 2.2 the Government decided to create two vertically integrated pillars in the power sector, which will result in two national champions rather than real rivals in the power market. Therefore, serious movements towards more competition in generation are not expected in the near future.

Electricity generators earned $€ 57.7$ million profit in 2005 . No company operated with a loss. Drava RC, which operates at the lowest average cost, achieved the best financial result. The major investment plans in generation were prepared by the HSE. Currently it is building the first of the five hydropower plants on the river Sava with total capacity of $189 \mathrm{MW}$. In the near future the major domestic investment would be the construction of the new coal-fired power plant in TPP Šoštanj with installed capacity of 600MW, which will replace three obsolete power plants after 2011. HSE has also very ambitious plans to invest in South East Europe. Some environmental constructions are also taking place in the electricity companies (EA, 2006).

At the end of 2005 there were 449 production facilities in Slovenia that had the status of a qualified producer, and were eligible to the subsidy through the preferential dispatch system. These are producers that produce electricity from renewable sources, in co-generation with an above-average efficiency and in an environmentally friendly way. The majority of those using renewable energy sources are hydropower plants. The share of others, which mostly use biomass and communal waste, is less than $1.5 \%$ (EA, 2005b).

By ratifying the Kyoto Protocol Slovenia committed itself to reducing greenhouse gas emissions by $8 \%$ by 2012 based on the 1986 level. Emissions trading is one of the instruments for achieving this objective. In line with Directive 2003/87/EC, the National Plan of Distributing Emission Coupons for 2005-2007 was prepared. On the basis of the data on annual emissions in the period 1999-2002, this document sets the number of emission coupons distributed by the state free of charge. In 2005 the thermal energy sector received more than two thirds of the coupons distributed in Slovenia (EA, 2006). As a large number of coupons was distributed to the companies, there was not much trading carried out.

The Renewable Energy Certification System (RECS) has been operating in Slovenia since 2004. RECs facilitate carbon-neutral renewable energy by providing a subsidy to electricity generated from renewable sources. RECs can be sold and traded and the owner of the REC can legally claim to have purchased renewable energy. In Slovenia RECS certificates are issued by the EA which also distributes and monitors their circulation in Slovenia. In 2004 the HSE together with electricity distribution companies started with the project "Blue Energy" which offers electricity generated in hydropower plants within the HSE group. 


\subsection{Transmission and Distribution}

The activities of the transmission system operator (TSO) and distribution system operator (DSO) are mandatory national public services. The transmission company Elektro-Slovenija, d.o.o. (ELES), provides the public service of transmission system operator (Table 3). In 2005 ELES operated at a profit of €8.99 million.

On 1 January 2003 Slovenia became a member of the European unified electricity market, in which unified and non-discriminatory rules regarding the payments for the use of the network in cross-border trading with electricity are enforced. ELES became a member of the ETSO-CBT settlement mechanism, in whose framework the national system operators settle the costs that are the result of electricity flows in individual transmission networks resulting from cross-border exchanges.

The Slovenian electric power system is relatively well connected to the electric power systems of the neighbouring countries:

- two 400kV power lines and one 220kV power line with Austria;

- a 400kV and a $220 \mathrm{kV}$ power line with Italy;

- three $400 \mathrm{kV}$ power lines, two $220 \mathrm{kV}$ power lines and three $110 \mathrm{kV}$ power lines with Croatia.

There are no power lines between Slovenia and Hungary.

It is perceived that in the past ten years ELES underinvested in the system. According to the ten-year development plan for the period 2005-2014, ELES expects to invest $€ 482.2$ million in the transmission network. ELES plans larger investments in the 400kV network for 2007-2011. They include the development of the national network (Beričevo-Krško), which was envisaged as inevitable to close the national transmission loop when the NPP Krško was built in 1978, as well as constructions of new interconnectors with Italy (Okroglo-Videm) and Hungary (Cirkovce-Hevitz). These connections will increase the cross-border transmission capacities in the east-west direction (EA, 2006).

Distribution utilities used to perform three activities: first, the public service of distribution system operator (DSO); second, the mandatory public service of supply to tariff customers; and third, commercial activities such as supply to eligible customers. They were obliged to keep separate accounts for each energy-related activity. As discussed in section 2.2, on 1 July 2007, with the reorganisation of distribution utilities, the DSO activity was legally separated from the five distribution companies.

Although the Slovenian electricity distribution utilities operated under quite similar conditions, there are some differences among them in terms of the size of the company, size of the service area and the number of customers (Table 4). The two smallest distribution companies also operate under less favourable conditions with respect to the surface area that they cover (i.e., larger share of forests, hills and mountains). On the other hand, the share of household customers and the share of sales to households are quite similar for all five distribution utilities. 
In 2005 all five electricity distribution companies operated at a profit of €20.4 million. They made profits in regulated activity related to power distribution (€12.3 million) and in commercial activities (€27.9 million). In the supply to tariff customers, they reported a huge loss (€21.7 million). This is the result of the governmental control of prices which kept them below costs during the last 15 years.

Under the Energy Act the distribution system operators are obliged to continually, considerably and effectively invest in the development and reconstruction of the electricity network. In 2005 they invested $€ 91.8$ million in the distribution network. In line with the ten-year development plan for the period 2005-2014 DSOs plan to invest $€ 996.9$ million in the distribution networks (EA, 2006).

\subsection{Power Exchange, Wholesale Market and Cross-Border Trading}

Borzen d.o.o. was established on 28 March 2001 to perform tasks of the obligatory public utility service for organising trading in the power exchange and other duties of promoting the utilisation of renewable sources and efficient energy use. At the end of 2005 Borzen had 24 employees. In 2005 Borzen generated $€ 2.38$ million of revenues, while the net profit amounted to $€ 96,395$ (Borzen, 2005).

In 2005 there were 15 full members of the power exchange. Traded power was $39,025 \mathrm{MWh}$ annually, which represented only $0.3 \%$ of the total Slovenian electricity consumption. This indicates a very low liquidity of the Slovenian wholesale market. The daily power market recorded $86 \%$ less operations than in 2004. One of the main reasons was the withdrawal of four distribution utilities from the power exchange, since they have purchased power by longterm bilateral contracts. Consequently, the number of participants in the market decreased, which led to a reshaped market structure. Another factor that contributed to a decrease in the liquidity of the power exchange was the early removal of the sale in the preferential dispatching regime from the power exchange. As a result, $99.7 \%$ of the consumed electricity was sold through bilateral contracts lasting from one to five years. No longer-term contracts have been signed in Slovenia (EA, 2006).

The largest growth in trade was recorded in the wholesale market, which was mainly a result of the accessibility of the neighbouring markets and differences in the electricity prices. Trade was mainly carried out from South East Europe to the EU countries north and west of Slovenia. In 2005 the Slovenian wholesale market included one large participant and a few smaller participants. Most of them also participated in the three neighbouring markets. They were buying electricity for Slovenian needs and for export to Italy in South East Europe and Central and Eastern Europe within the limited cross-border transmission capacities.

For allocation of cross-border transmission capacities the "pro rata method" was used until 1 July 2007 as a derogation applied to Slovenia, which allowed the use of non-market-based methods. The biggest share of cross-border 
capacities was allocated to the HSE which additionally strengthened its dominant position in the power market. In 2005, the power exchange Borzen started to carry out daily auctions for the allocation of free cross-border transmission capacities with Croatia, Austria and Italy. However, only a small amount of capacities was allocated by auctions since the available capacities were mostly allocated by tenders. Congestion continually occurs on the Slovenian-Italian border (in the direction towards Italy), causing huge problems for the transmission system operator. In order to prevent this, the transmission system operator has to occasionally restrict capacities on the SlovenianCroatian border for imports from Croatia. For the same reason (to restrict the flows towards Italy) the transmission system operator also has to restrict flows on the Slovenian-Austrian border.

The power exchange Borzen establishes the imbalances of the balance groups and subgroups by calculating the difference between the total realisation of a balance group or subgroup and the operation schedule of the same balance group or subgroup. The imbalances are established for each accounting interval (i.e., one hour). Balance groups receive from Borzen monthly financial accounts related to the imbalance amounts that provide the basis for issuing the bills. In 2005 there were ten balance groups operating in Slovenia (EA, 2006). The largest balance group with the HSE as a leader unified producers with more than $95 \%$ of installed capacity under one roof. Among state owned utilities only one distribution utility, Elektro Maribor, was not part of the HSE's balance group as it created its own balance group.

Balance groups are often blamed for having a negative impact on developing competition in the retail market. Within each balance group imbalances between operation schedule and actual supply of its members cancel out. Therefore, bigger groups are typically characterised by smaller imbalances in relative terms (i.e., as a share of total supply). In this way the members of a balance group reduce risk of the lack or excess of supply, since the group somehow works as one supplier. If a new (and typically small) supplier is not able to join any existing balance groups, volatility in demand would cause constant imbalances that would be detrimental to its profits.

\subsection{Retail Market and Supply}

Thirteen suppliers of electricity were active in the retail market in 2005 . They supplied power to seven eligible customers connected to the transmission network, and to 97,018 eligible customers connected to the distribution networks. Eligible customers also had the possibility to buy electricity in the power exchange Borzen and in foreign exchanges subject to the availability of the cross-border transmission lines. Thus, $11.3 \%$ of the total 870,593 customers had the right to choose their supplier in 2005. Their consumption amounted to $75 \%$ of the electricity consumed in Slovenia. Eligible customers on the transmission and distribution network consumed $53 \%$ and $22 \%$ of electricity, respectively. Households (tariff customers), which are the most numerous group $(773,568$ customers $)$, consumed $25 \%$ of the electricity.

The main supplier is still the HSE, which is also the largest producer. Other suppliers have a very low generation of their own or do not have any. In 2005 
the HSE had the largest market share in supply to eligible customers connected to the transmission and distribution network. It was followed by two distribution companies, namely Elektro Ljubljana and Elektro Maribor. If we take into account only eligible customers connected to the distribution network, then the largest share is held by Elektro Ljubljana, followed by the four distribution companies and the HSE.

The degree of competitiveness in the electricity retail market is rather low. The market share of the three largest suppliers amounts to $71 \%$. Moreover, the HSE together with the five distribution utilities supply $97 \%$ of power to eligible customers. In spite of the fact that no company has a dominant position, the concentration in the retail market is quite high.

Most of the contracts for supply to end customers were signed by distribution utilities. They were supplying electricity bought in the wholesale bilateral market, while other suppliers were also buying electricity in the power exchange. The remaining companies trading in the power exchange Borzen are also active in the wholesale market. They are showing an increasing interest in the supply of electricity to end customers. In 2005 the market share of the suppliers other than distribution companies and the HSE increased by about $3 \%$. Six such companies were active.

The small number of suppliers in the domestic wholesale market affects the dynamics of supplier switching. In 2005, 4,701 eligible customers changed supplier, which was less than $5 \%$ of all eligible customers. Only $1 \%$ of eligible customers connected to the distribution networks decided to switch supplier (EA, 2006).

\section{Impact of Reforms and Suggestions for Further Improvements}

Over the past eight years Slovenia has been relatively successful in implementing reforms in the electricity sector. Reforms have been carried out in line with the EU Electricity Directives (96/92/EC and 2003/54/EC). According to the classification of Jamasb et al. (2004) the electricity reforms in Slovenia carried out so far comprise of:

(i) market liberalisation (i.e., opening the electricity market);

(ii) allowing regulated TPA to eligible customers;

(iii) unbundling of generation, transmission, distribution and supply of electricity;

(iv) formation of an organised power market;

(v) establishment of an independent regulatory body; and

(vi) regulatory reform and adoption of incentive-based price cap regulation.

Nevertheless, some objectives of the reforms have not been fully achieved. Although the market was fully liberalised on 1 July 2007, the level of competition in generation and supply remains relatively low. This is the result of the small size of the electricity market, the structure of market participants, 
the structure of production sources and cost differentials between generators, the limited cross-border transmission capacities and the ownership structure of the companies in the electricity sector.

There have been some attempts to increase competition in the Slovenian electricity market by creating two vertically integrated pillars. Nonetheless, it is argued that two companies or pillars are not sufficient for creating competitive conditions in the market. Another alternative would be to break up the generation holding HSE, but this does not seem to be a viable solution since companies in the holding use different technologies and operate at a very different average cost. Another limitation to competition in the Slovenian electricity sector is its net importer position and limited cross-border capacities. Therefore, even the most expensive generation unit is needed occasionally to meet the domestic demand for electricity. The possible solutions to enhance competition are thus building new generation facilities and interconnection capacities. Nevertheless, as long as electricity prices in Italy remain significantly higher than in Slovenia, there will be incentive for trading (i.e., import of electricity to Slovenia and further export to Italy).

Concentration in the Slovenian retail market is also quite high as the HSE together with five distribution companies supply $97 \%$ of electricity to final customers. On 1 July 2007 the distribution system operators were legally separated from other activities carried out by distribution companies including the supply to end-users. A single distribution system operator SODO was established by merging the five DSOs. It is expected that the reorganisation of distribution companies would improve transparency and bring equal conditions for all suppliers of electricity. Whether this would in turn help to increase competition in the retail market remains to be seen.

For the time being, distribution companies remain owners of the distribution network, so that SODO has to rent the network as well as services connected to the infrastructure from the distribution companies. Undergoing separation can thus be viewed merely as a formal or administrative solution that would change as little as possible and at the same time satisfy the requirement on legal separation of obligatory public service from market activities. However, this is not yet the final solution. In the future the Government may decide to transfer the infrastructure as well as employees from distribution companies to SODO. In addition, the reorganisation of distribution companies also facilitates mergers with generating companies which is in line with the proposed creation of the two pillars.

For the price regulation of transmission and distribution networks, an incentivebased price cap regulation has been applied since 2003. Price caps have been adjusted in line with benchmarking results used to set efficiency targets for the companies. Regulation is carried out by the Energy Agency (EA) which should act as an independent regulatory body. However, its independence is in fact questionable as the Government had intervened several times to prevent increases in the network charges proposed by the EA. 
With full opening of the market on 1 July 2007, households became eligible customers. Electricity prices for households are no longer controlled by the Government, but are set in the market. In the first few months after the full opening of the electricity market households did not witness any significant changes. So far distribution companies and other suppliers have not yet started to compete for households. The reason can be probably found in low electricity prices for households, which are currently below the full-cost level. The prices in the near future are thus expected to rise, which would happen gradually in order to avoid strong resistance from the public. This is the most likely scenario as the state is still the majority owner of distribution utilities. As household prices have not yet changed, there is no incentive to switch current supplier.

As Slovenia is one of the EU member states with the largest state ownership in electricity companies, further reforms of the electricity sector considered by the Government involve privatisation. According to the Government proposal, only the largest group of generators, HSE, is predicted for privatisation, whereas for the time being the NPP Krško, the transmission company and all five distribution companies remain in state ownership. This is contrary to the practice of other transition countries (such as the Czech Republic, Hungary and Poland) which opened the distribution sector to private and also foreign owners. 


\section{References}

1. EA (The Energy Agency of the Republic of Slovenia) (2004a). Report on the Energy Sector in Slovenia for 2003, Maribor.

2. EA (2004b). Act Determining the Methodology for Charging for the Network Charge and the Methodology for Setting the Network Charge for Electricity Networks (The Official Gazette of the Republic of Slovenia, No 84/2004).

3. EA (2005). Akt o določitvi metodologije za obračunavanje omrežnine in metodologije za določitev omrežnine in kriterijih za ugotavljanje upravičenih stroškov za elektroenergetska omrežja (Act Determining the Methodology for Charging for the Network Charge and the Methodology for Setting the Network Charge and the Criteria for Establishing Eligible Costs for Electricity Networks). The Official Gazette of the Republic of Slovenia, No $\underline{121 / 2005}$.

4. EA (2005b). Report on the Energy Sector in Slovenia for 2004, Maribor.

5. EA (2006). Report on the Energy Sector in Slovenia for 2005, Maribor.

6. EA (2006b). Sklep o določitvi omrežnine za uporabo elektroenergetskih omrežij in korekcijskih faktorjev za izravnavo prihodka iz omrežnin. (Decision on Setting the Network Charge for the Use of Electricity Networks and the Correction Factors for Balancing the Revenues from the Network Charges). The Official Gazette of the Republic of Slovenia, No 122/2006).

7. Filippini, M., Hrovatin, N., Zorić, J. (2004). Efficiency and regulation of the Slovenian electricity distribution companies. Energy policy, vol. 32, pp. 335344.

8. Hall, D. (1998): Trends in energy privatisation in Central and Eastern Europe. London: University of Greenwich.

9. Hrovatin, N. (1999). Industrial structure and privatisation of the Slovenian electricity industry. Economia delle fonti di energia e dell'ambiente, volume 42, No. 2, pp. 143-183.

10. Hrovatin, N. (2001). Restructuring the Slovenian Electricity Industry. Eastern European Economics 39 (5), pp. 6-30.

11. Hrovatin, N., Zorić, J., Scarsi G., Paripović, M., Senčar, M. (2005). Relative Performance of Electricity Distribution Utilities from Slovenia, the Netherlands and the UK: An Application of Data Envelopment Analysis. 3rd Conference on Public Sector, June 30 - July 1, 2005, EF: Ljubljana.

12. Jamasb, T., Mota, R., Newbery, D., Pollitt, M. (2004). Electricity Sector Reform in Developing Countries: A Survey of Empirical Evidence on Determinants and Performance. Cambridge Working Papers in Economics CWPE 0439.

13. Košir, M. (2007). Reorganisation of electricity distribution (Reorganizacija elektrodistribucije). Delo, 23 March 2007, Ljubljana.

14. Kwong-leung, T. (1997). Efficiency of the Private Sector: a Critical Review of Empirical Evidence from Public Services, International Review of Administrative Sciences 63, pp. $459-474$. 
15. Simoneti, M., Rojec, M. and Gregorič, A. (2004). Privatisation, Restructuring and Corporate Governance of the Enterprise Sector. In Mrak, M., Rojec M., Silva-Jaureguli, C. (eds.). From Yougoslavia to the European Union. The World Bank, pp. 224-243.

16. Tajnikar, M., Hrovatin, N., Lahovnik, M., Ogrin, N., Rant, M., Došenovič, P., Zorić, J. (2002). Projekt koncentracije kapitala in poslovnih funkcij $v$ elektrodistribucijskem sistemu Republike Slovenije. (The project on concentration of capital and business functions in the electricity distribution system of the Republic of Slovenia). Ljubljana: Faculty of Economics.

17. The Law on Ownership Transformation of Business Enterprises (1993) (in Slovenian: Zakon o lastninskem preoblikovanju podjetij). Official Gazette of the Republic of Slovenia, No. 31.

18. The Public Utilites Act (1993) (in Slovenian: Zakon o gospodarskih javnih službah). Official Gazette of the Republic of Slovenia, No.32.

19. Tomšič, M. (1994). Divestment and Privatisation of the Power Distribution Companies in Slovenia. Phare/EBRD Preparatory Assistance Project. Strategy for the Privatization of Slovenian Power Sector. Project Reports. 


\section{Sources}

1. Amendments of the Energy Act (EZ-A) (2004). Official Gazette of the Republic of Slovenia, No. 51/2004.

2. Amendments of the Energy Act (EZ-B) (2006). Official Gazette of the Republic of Slovenia, No. 118/06.

3. Annual reports of Slovenian electricity distribution utilities for 2005.

4. Annual reports of Slovenian generation companies for 2005.

5. Borzen (2006). Report 2005. Ljubljana.

6. Directive 2003/54/EC of the European Parliament and of the Council of 26 June 2003 concerning common rules for the internal market in electricity and repealing Directive 96/92/EC - Statements made with regard to decommissioning and waste management activities, OJ L 176.

7. Directive 2003/87/EC of the European Parliament and of the Council of 13 October 2003 establishing a scheme for greenhouse gas emission allowance trading within the Community and amending Council Directive 96/61/EC, OJ L 275.

8. Directive 96/92/EC of the European Parliament and of the Council of December 19, 1996 Concerning Common Rules for the Internal Market in Electricity, OJ L 027.

9. ELES (2006). Electric Power System of Slovenia 2005. Ljubljana.

10.Energy Act (EZ) (1999). Ljubljana, Official Journal of the Republic of Slovenia, No. 79/99.

11. Energy Act (EZ-UPB1) (2005). Official Gazette of the Republic of Slovenia, No. $26 / 05$.

12. National Plan of Distributing Emission Coupons for 2005-2007 (2004). Official Journal of the Republic of Slovenia, No. 112/04, 131/04 and 132/04-corrections.

13. Operational Programme for Reducing Greenhouse-Gas Emissions (2004). Ministry of the Environment, Spatial Planning and Energy. Ljubljana.

14. Statistical Yearbook 2006. Statistical Office of the Republic of Slovenia SORS. Ljubljana.

15. World Bank (2006). Country brief 2006 [http://worldbank.org/]. 


\section{Tables}

Table 1: Use-of-Network Prices and End-User Prices in 2005 for Two Groups of Typical Industrial (Eligible) Customers and a Group of Household Customers

\begin{tabular}{|c|c|c|c|}
\hline Price category (cEUR/kWh) & $\begin{array}{l}\text { Ind. customer } 1 \\
(4 \mathrm{MW}, 24 \mathrm{GWh})\end{array}$ & $\begin{array}{l}\text { Ind. customer } 2 \\
(50 \mathrm{~kW}, 50 \mathrm{MWh})\end{array}$ & $\begin{array}{c}\text { Households } \\
(3500 \mathrm{kWh} / \text { year })\end{array}$ \\
\hline Transmission network charge & 0.26 & 0.76 & 0.66 \\
\hline Distribution network charge & 0.53 & 3.49 & 3.13 \\
\hline Ancillary services & 0.05 & 0.32 & 0.64 \\
\hline Preferential dispatch & 0.25 & 0.38 & 0.55 \\
\hline Energy Agency (EA) & 0.02 & 0.02 & 0.02 \\
\hline Borzen & 0.01 & 0.01 & 0.01 \\
\hline Supply costs & 1 & I & 0.25 \\
\hline Use-of-network price & 1.12 & 4.99 & 5.01 \\
\hline Energy & 4.13 & 5.54 & 3.48 \\
\hline $\begin{array}{l}\text { Final price of electricity } \\
\text { (without VAT) }\end{array}$ & 5.25 & 10.53 & 8.49 \\
\hline VAT $(20 \%)$ & 1.05 & 2.11 & 1.70 \\
\hline Final price including VAT & 6.30 & 12.64 & 10.19 \\
\hline
\end{tabular}

Source: $E A$ (2006).

Table 2: Installed Capacities (in MW), Production of Electricity (in GWh) and the Number of Employees in Electricity Generation in 2005

\begin{tabular}{lrrr}
\hline Type of production & $\begin{array}{c}\text { Installed } \\
\text { capacity (MW) }\end{array}$ & \multicolumn{1}{c}{$\begin{array}{c}\text { Production } \\
\text { (GWh) }^{*}\end{array}$} & $\begin{array}{c}\text { Nr. of } \\
\text { employees }\end{array}$ \\
\hline 1. Hydroelectric power plants (HPP) & $\mathbf{8 6 4}$ & $\mathbf{3 , 0 3 6}$ & $\mathbf{5 4 4}$ \\
- Drava RC & 575 & 2,451 & 294 \\
- Soča RC & 136 & 306 & 126 \\
- Sava RC & 153 & 280 & 126 \\
\hline 2. Thermal power plants (TPP) & $\mathbf{1 , 1 4 8}$ & $\mathbf{4 , 6 0 1}$ & $\mathbf{1 , 2 3 5}$ \\
- TPP Šoštanj & 672 & 3,572 & 561 \\
- TPP Brestanica & 312 & 33 & 123 \\
- TPP Trbovlje & 164 & 588 & 250 \\
- CHP TE-TOL & $\mathbf{1 1 2}$ & 407 & 301 \\
\hline 3. Nuclear power plant NPP Krško & $\mathbf{6 7 0}$ & $\mathbf{2 , 8 0 7}$ & $\mathbf{5 7 0}$ \\
4. Small generators (transmission and & $\mathbf{1 9 6}$ & $\mathbf{4 1 7}$ & n.a. \\
distribution network) & & & \\
\hline Total & $\mathbf{2 , 9 9 0}$ & $\mathbf{1 0 , 8 6 1}$ & $\mathbf{2 , 3 4 9}$ \\
\hline
\end{tabular}

* $-50 \%$ of NPP Krško taken into account

Source: Annual reports of electricity generation utilities for 2005, EA (2006).

Table 3: Physical Data on Transmission Company ELES in 2005

\begin{tabular}{lr}
\hline Transmission network & 2005 \\
\hline Length of transmission lines $(\mathrm{km})$ & 2,534 \\
$-400 \mathrm{kV}(\mathrm{km})$ & 507 \\
$-220 \mathrm{kV}(\mathrm{km})$ & 328 \\
$-110 \mathrm{kV}(\mathrm{km})$ & 1,699 \\
Peak load (MW) & 2,043 \\
Electricity off-take [production + import] (GWh) & 22,615 \\
Electricity pass through [domestic users + export] (GWh) & 22,338 \\
\hline Electricity sold in Slovenia (GWh) & 12,790 \\
- Sales to direct users (GWh) & 2,775 \\
- Sales to distribution companies (GWh) & 10,015 \\
Nr. of employees (end of year) & 471
\end{tabular}

Source: ELES (2006). 
Table 4: Physical Data on Distribution Utilities in 2005

\begin{tabular}{lrrrrrr}
\hline Indicator & $\begin{array}{l}\text { Elektro } \\
\text { Celje }\end{array}$ & $\begin{array}{l}\text { Elektro } \\
\text { Gorenjska }\end{array}$ & $\begin{array}{l}\text { Elektro } \\
\text { Ljubljana }\end{array}$ & $\begin{array}{l}\text { Elektro } \\
\text { Maribor }\end{array}$ & $\begin{array}{l}\text { Elektro } \\
\text { Primorska }\end{array}$ & Total \\
\hline Area $\left(\mathrm{km}^{2}\right)$ & 4,345 & 2,091 & 5,231 & 3,992 & 4,335 & 19,994 \\
Network length (km) & 15,163 & $4,640^{1}$ & 17,880 & 15,196 & 8,246 & 61,125 \\
Peak load (MW) & 309 & 163.3 & 599.5 & 322.6 & 285 & $1,679.4$ \\
\hline Nr. of customers & 158,246 & 81,949 & 306,027 & 202,302 & 120,662 & 869.186 \\
- households (\%) & 89.2 & 88.7 & 90.3 & 92.9 & 88.4 & 90.4 \\
- eligible customers (\%) & 10.8 & 11.3 & 9.7 & 7.1 & 11.6 & 9.6 \\
Electricity sold (GWh) & $1,395.6$ & 939.8 & $3,269.9$ & $2,096.5$ & $1,542.1$ & $9,243.9$ \\
- households (\%) & 37.9 & n.a. & 31.1 & 37.2 & 28.3 & 33.6 \\
- eligible customers (\%) & 62.1 & n.a. & 68.9 & 62.8 & 71.7 & 66.4 \\
\hline Employees (end of year) & 710 & 316 & 983 & 863 & 511 & 3,383 \\
\hline
\end{tabular}

- data for 2003

Source: Annual reports of electricity distribution utilities for 2005.

\section{Figures}

Figure 1: Slovenian Electricity Sector in 2005 (Data in GWh)

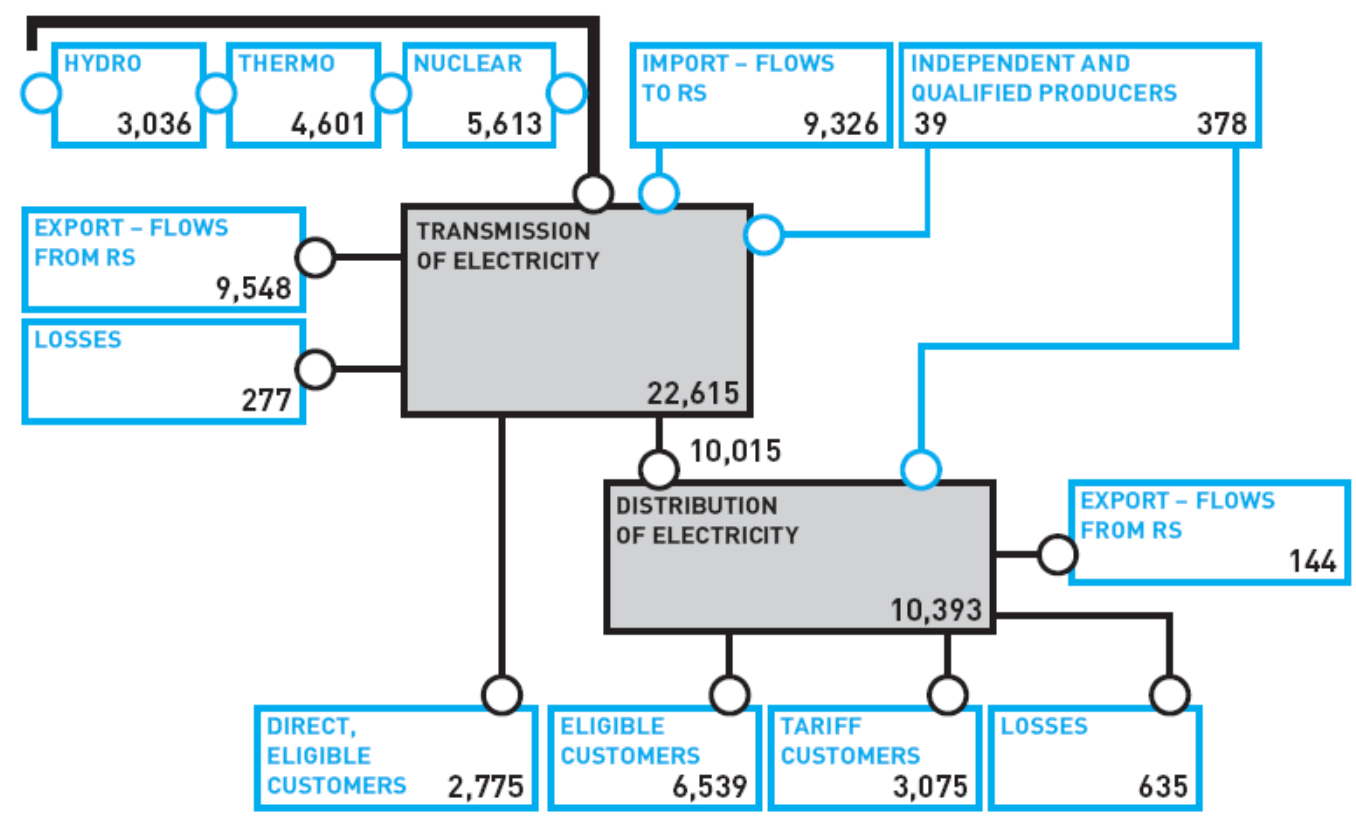

Source: $E A$ (2006). 